\title{
Persepsi Pemustaka atas Suara Gamelan terhadap Tingkat Kenyamanan Literasi di Perpustakaan Lingkungan Fakultas Seni Pertunjukan (FSP) ISI Surakarta
}

\author{
Sartini ${ }^{1}$, Sugeng Priyanto ${ }^{2}$ \\ ${ }^{1}$ UPT Perpustakaan Institut Seni Indonesia Surakarta \\ Jalan Ki Hajar Dewantara No.19, Jebres, Surakarta, Jawa Tengah 57126 \\ HP.: 08122590313; Email: titinpriyanto@yahoo.co.id \\ ${ }^{2}$ UPT Perpustakaan Universitas Diponegoro \\ Jalan Prof. Sudharto, SH., Tembalang, Semarang \\ HP.: 08122921473; Email: sugengpriyanto76@gmail.com
}

\begin{abstract}
Abstrak
Riset ini dilatarbelakangi oleh fenomena efek suara gamelan yang terjadi di ruang kuliah yang terdengar hingga perpustakaan di lingkungan FSP ISI Surakarta. Yang ingin diungkap dalam riset ini adalah: (1) Bagaimana pemustaka meresepsi suara gamelan ketika melakukan aktivitas literasi di Perpustakaan Lingkungan Fakultas Seni Pertunjukan? (2) Bagaimana implikasi suara gamelan terhadap tingkat kenyamanan aktivitas literasi di Perpustakaan lingkungan Fakultas Seni Pertunjukan? Untuk mengungkap permasalahan digunakan teori kenyamanan Katharine Kolcaba tentang kenyamanan psikospiritual dan kenyamanan lingkungan serta psikologi musik Djohan Salim tentang musik dan emosi manusia. Penelitian ini dilakukan mengunakan kombinasi model, atau desain sequential explanatory (urutan pembuktian), yaitu metode yang menggabungkan kuantitatif dan kualitatif secara beurutan. Tahap pertama dilakukan dengan metode kuantitatif, yakni dengan mendistribusikan kuesioner kepada para pemustaka. Lantas selanjutnya dilakukan dengan metode kualitatif meliputi: observasi, wawancara, dokumentasi, dan analisis. Hasil dari penelitian ini adalah: (1) Suara gamelan dirasa tidak mengganggu; (2) Suara gamelan dianggap lazim, sebagai kampus seni, dan dirasa bukan menjadi hal yang menggangu dalam aktivitas berliterasi; (3) Suara gamelan dianggap sebagian pemustaka sebagai hal yang memberikan pengaruh baik terhadap kenyamanan mereka, artinya secara psikologi memberikan dampat baik dan tentu membuat nyaman di dalam ruangan; (4) Suara gamelan dianggap tidak perlu menjadi hal yang diperdebatkan; (5) Kenyamanan selalu berbanding lurus dengan pengalaman ketubuhan manusia, suara gamelan merupakan entitas yang menjadi pengalaman mayoritas mahasiswa ISI Surakarta, sehingga di dalam aktivitas literasi tidak menjadikan gangguan secara umum.
\end{abstract}

Kata kunci: kenyamanan; perpustakaan; pengaruh; suara gamelan

\begin{abstract}
Perception of The Minister of Gamelan Sound Towards The Level of Literacy Comfort In the Environmental Library of the Faculty of Performing Arts (FSP) ISI Surakarta. This research is motivated by the phenomenon of gamelan sound effects that occur in lecture halls which are heard to the library in the Faculty of Performing Arts at Indonesian Institute of the Arts Surakarta environment. This research wants to reveal: (1) How does the user perceive gamelan sound when doing literacy activities in the Environmental Library of the Performing Arts Faculty? (2) How the implications of the voice of gamelan to the comfort level of literacy activities in the Library of the Performing Arts Faculty? To uncover the problem Katharine Kolcaba's comfort theory is used about psychospiritual comfort and environmental comfort and Djohan Salim's music psychology about music and human emotions. This research was conducted using a combination of models, or sequential explanatory designs (sequences of proof), a method that combines quantitative and qualitative sequentially. The first stage is done by quantitative methods, namely by distributing questionnaires to users. Then the
\end{abstract}


next is done by qualitative methods include: observation, interviews, documentation, and analysis. The results of this research are: (1) the sound of the gamelan is consistently felt not disturbing; (2) the sound of gamelan is considered to be common, as an art campus, and is not considered to be a disturbing thing in literated activities; (3) the sound of gamelan is considered part of the visitors as a matter of good influence on their comfort, meaning psychologically giving a good impact and of course making it comfortable in the room; (4) the sound of the gamelan is unnecessarily staged; (5) comfort is always directly proportional to the experience of human body, the sound of gamelan is an entity that is the experience of the majority of Indonesia Insititute of the Arts Surakarta students, so that literacy activities do not cause general disturbance.

Keywords: convenience; perception; library; sound of gamelan

\section{A. Pendahuluan}

Terobosan inovasi di berbagai perpustakaan baik di dalam maupun luar negeri memiliki keunikan tersendiri demi memikat sekaligus memberikan rasa nyaman bagi pemustaka. Selama ini program unggulan di beberapa perpustakaan, hanya berkutat pada aspek interior ruangan yang didesain senyaman mungkin agar para pemustaka betah di perpustakaan. Lebih dari itu, terobosan auditif juga tengah diluncurkan diberbagai perpustakaan, yakni dengan memperdengarkan musik di ruangan perpustakaan untuk memberikan efek nyaman bagi para pemustaka. Di Perpustakaan Cikini, kompleks Taman Ism'ail Marzuki, Jakarta Pusat menghadirkan ruangan yang terdapat suara musik untuk dapat memikat pemustaka agar dapat berkunjung ke perpustakaan tersebut (detiknews. com).

Teknologi digital yang berkembang di perpustakaan juga meningkatkan pemanfaatan koleksi perpustakaan ketika ada kebutuhan untuk menyelesaikan tugas yang diberikan oleh dosen maupun untuk menyelesaikan tugas akhir. Selain memanfaatkan koleksi dengan membaca, meminjam menyalin dan memfotokopi, mahasiswa sudah memanfaatkan koleksi repository institusi (Wahyuntini, 2021). Hal ini dapat dijadikan modal layanan bagi perpustakaan.

Di lingkungan perpustakaan perguruan tinggi di Indonesia yang berbasis seni seperti ISI, kenyamanan pengunjung merupakan salah satu aspek terpenting dalam aspek pelayanan. Hal ini sesuai dengan hasil penelitian bahwa terdapat pengaruh positif antara pelayanan UPT
Perpustakaan ISI Yogyakarta dengan prestasi akademik mahasiswa Fakultas Seni Rupa Institut Seni Indonesia Yogyakarta (Bandono, 2021).

Langkah-langkah di atas, sebagai sebuah terobosan yang memiliki tujuan sama yaitu, memberikan kenyamanan terhadap para pengunjung perpustakaan. Lantas sejauhmana efektifitas pengaruhnya terhadap para pengunjung, data kongkret apa yang dijadikan indikator kenyamanan pengunjung? Tulisan ini hadir dalam rangka menjawab pertanyaan tersebut tetapi dengan menggunakan sudut pandang yang berbeda, yakni persepsi pemustaka atas suara gamelan terhadap tingkat kenyamanan literasi di perpustakaan lingkungan Fakultas Seni Pertunjukan (FSP) ISI Surakarta.

Fenomena tersebut memang bukan menjadi hal baru, sudah tentu di kampus seni, lingkungannya terdengar suara musik atau gamelan. Akan tetapi, riset ini mencoba melihat dari sisi yang berbeda, dan tentu belum banyak dilakukan oleh akademisi seni khususnya, apalagi menggunakan sudut pandang literasi. Fakta itu yang mendorong penulis meneliti efek suara gamelan terhadap kenyamanan pemustaka. Suara gamelan, di lingkungan ISI Surakarta khususnya Fakultas Seni Pertunjukan (FSP) merupakan pengalaman auditif yang secara intens dialami oleh seluruh mahasiswa dan sivitas akademika. Suara itu, seolah sudah nyarira atau embody di dalam tubuh mereka. Jika di tempat lain, musik berusaha dihadirkan di ruangan perpustakaan, lantas bagaiamana jika suara gamelan, dari ruang kuliah setiap hari terdengar sampai di ruangan perpustakaan? Persitiwa itu yang akan diungkap berkaitan dengan proses literasi para 
pemustaka di lingkungan FSP ISI Surakarta.

Ditinjau dari aspek kepentingan, secara premature memang bocoran suara gamelan tersebut tidak menjadi kebutuhan bunyi yang disengaja dihadirkan oleh UPT Perpustakaan ISI Surakarta, bahkan lebih ekstrem lagi, apakah suara tersebut justru malah mengganggu, mengingat suaranya yang lumayan keras jika berada di ruang perpustakaan. Pandangan tersebut tidak serta merta digunakan sebagai indikator yang valid. Melihat kultur dan psikologi mahasiswa dan sivitas akademika Fakultas Seni Pertunjukan, memiliki anggapan bahwa suara gamelan bagi mereka sudah menyatu dengan alam bawah sadar. Persoalan itulah yang kemudian melatarbelakangi riset ini dilakukan.

\section{B. Metode Penelitian}

Riset ini menggunakan metode kombinasi model, atau desain sequential explanatory (urutan pembuktian), yaitu metode yang menggabungkan kuantitatif dan kualitatif secara berurutan. Tahap pertama dilakukan dengan metode kuantitatif, yakni dengan mendistribusikan kuesioner kepada para pemustaka. Lantas selanjutnya dilakukan dengan metode kualitatif. Metode tersebut berperan untuk mengungkap data yang bersifat deskriptif, komparatif dan asosiatif, sekaligus memperdalam, memperluas, data kuantitatif yang telah diperoleh (Sugiyono, 2013: 486). Langkah penelitiannya menggunakan kuantitatif terlebih dahulu dengan mendistribusikan kuesioner kepada para pemustaka. Selanjutnya berdasarkan kuesioner tersebut dilakukan analisis dan dilanjutkan dengan metode kualitatif dengan wawancara mendalam dengan para pemustaka. Kedua data tersebut dianalisis dan ditarik kesimpulan.

\section{Hasil dan Pembahasan}

Perpusatakaan di lingkungan Fakultas Seni Pertunjukan ISI Surakarta terdiri dari Perpustakaan Pusat, Perpustakaan Jurusan Karawitan dan Etnomusikologi, Perpustakaan Jurusan Seni Tari, dan Perpustakaan Jurusan Pedalangan dan Teater. Semua perpustakaan tersebut secara langsung terpapar suara gamelan dari berbagai penjuru ruangan termasuk suara gamelan dari jurusan masing-masing. Fakta itu, menunjukkan bahwa fenomena auditif tentang gamelan, hampir tidak mungkin dihindari oleh semua perpustakaan yang ada. Karena setiap jurusan yang terdapat perpustakaan, suara gamelan selalu terdengar setiap hari sebagai aktivitas perkualiahan, baik itu Jurusan Seni Karawitan, Etnomusikologi, Tari, Pedalangan, dan Teater.

Kenyataan di atas merupakan deskripsi lingkungan perpustakaan di ISI Surakarta. Kondisi lingkungan yang demikian, secara tidak langsung berpengaruh terhadap anggapan atau value dari sivitas akademika ISI Surakarta, utamanya para mahasiswa. Secara tidak langsung, lingkungan membentuk psikologi mereka terkait dengan suara gamelan terhadap kenyamanan berliterasi. Secara normatif, paparan suara gamelan tersebut dianggap sebagai polusi udara, jika konteksnya sedang tidak dalam mendengar atau memainan gamelan. Apalagi dengan suara gamelan yang random dari berbagai penjuru dengan beragam gendhing yang dibunyikan, hal itu seharusnya menjadi masalah tersendiri.

Terdapat teori yang relevan untuk menggambarkan fenomena di atas, yaitu tentang pergeseran makna tentang kebisingan. Oliver Ballay (2005: 14) menyatakan bising di sekitar rumah atau lingkungan disebut dengan neighbourdhood noice, yaitu karena sudah terbiasa, manusia tidak terganggu dengan bising di sekitar rumah atau lingkungan. Apa yang dinyatakan oleh Ballay, relevan dengan kondisi lingkungan di perpustakaan ISI Surakarta. Kebiasaan paparan suara gamelan yang terus menerus, membentuk pergeseran makna tentang konsep kebisingan. Hal itu memiliki konsekuensi logis terhadap persepsi tentang kenyamanan, salah satunya kenyamanan dalam berliterasi di perpustakaan lingkungan Fakultas Seni Pertunjukan ISI Surakarta.

\section{Persepsi Pemustaka terhadap Suara Gamelan di Perpustakaan}

Mayoritas responden berpendapat, suara gamelan merupakan pemandangan auditif 
setiap hari di lingkungan kampus ISI Surakarta. Mendengar gamelan seolah menjadi hal yang biasa. Tubuh yang setiap hari terpapar gelombang suara gamelan, seakan menjelma menjadi pengalaman bawah sadar oleh responden. Oleh sebab itu, keberadaan suara gamelan di ruang perpustakaan tidak berpotensi mengganggu, karena alam bawah sadar para mahasiswa, khususnya Fakultas Seni Pertunjukan ISI Surakarta, memiliki ikatan emosional tersendiri terhadap suara gamelan, bahkan secara umum dengan musik.

Dilihat secara seksama, karakter pemustaka di ISI Surakarta dibandingkan dengan kampus lain, memiliki kondisi psikologi yang berbeda. Kendati secara praktik literasi di perpustakannya sama, namun konstruksi psikologi terkait gangguan auditif, menjadi beda. Tubuh mereka seperti akrab dengan suara gamelan di manapun berada. Hal itulah yang membuat definisi kenyamanan pemustaka dalam menafsir suatu suasana dalam perpustakaan. Pengalaman ketubuhan dari seseorang, memengaruhi ukuran kenyamanan.

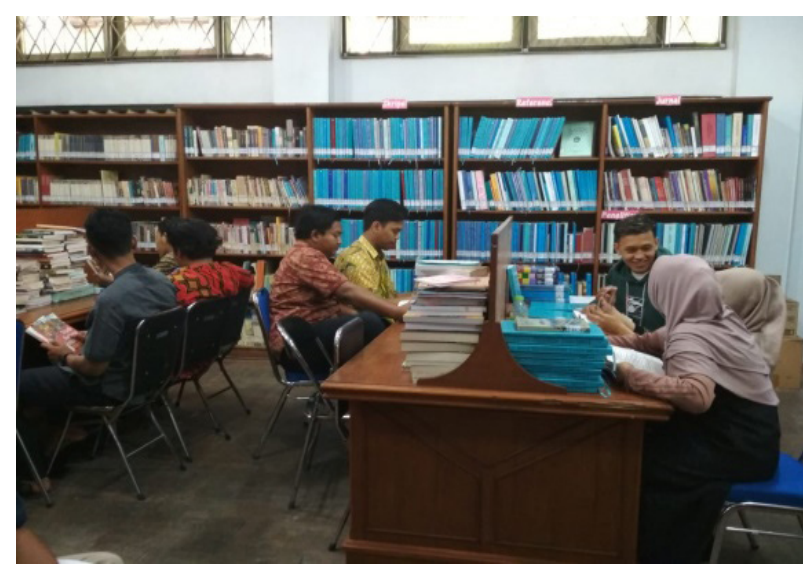

Gambar 1: Potret suasana dan pemustaka di Perpustakaan Jurusan Karawitan ISI Surakarta. (Foto: Sartini, 2019)

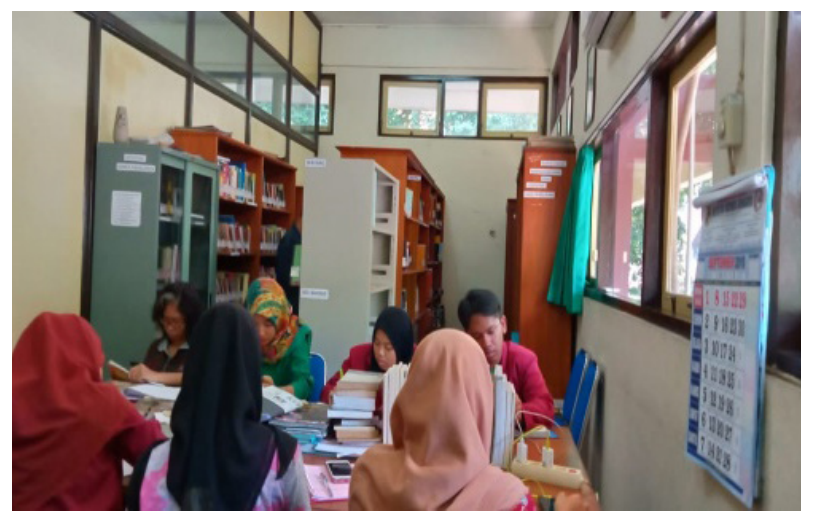

Gambar 2: Potret suasana dan pemustaka di Perpustakaan Jurusan Pedalangan ISI Surakarta. (Foto: Sartini, 2019)
Jika berbicara dalam konteks kenyamanan pemustaka di ruang perpustakaan ISI Surakarta, setiap mahasiswa memiliki preferensi terhadap konsep kenyamanan yang hampir memiliki kesamaan ukuran. Artinya ukuran itu secara tidak langsung dibentuk melalui kebiasaan mereka di lingkungan kampus ISI Surakarta. Suara gamelan, menjadi konsumsi auditif yang masif di kampus ISI Surakarta. Suara gamelan ada di setiap tempat, seperti: kantin, toilet, parkiran, taman, tempat ibadah serta ruang perpustakaan. Kondisi lingkungan demikian disebut dengan istilah soundscape, Sinakagawa menyebutnya dengan istilah suara lingkungan. Soundscape berarti pemandangan berupa bunyi. Kosep ini diciptakan oleh Murray Schafer untuk mengatasi polusi bunyi (Nakagawa, 2000: 110).

Pergeseran makna atas gangguan kebisingan tersebut, tampaknya itulah yang terjadi di lingkungan ISI Surakarta. Bukan berarti pergeseran tersebut bersifat negatif, namun lebih bersifat perubahan persepsi atas suara gamelan yang ada di lingkungan ISI Surakarta khususnya ruang perpustakaan. Kenyataan itu yang lantas menjadikan pemahaman baru, bahwa paparan atau gangguan auditif berupa suara gamelan atau musik yang lain, belum tentu dimaknai sebagai polusi bunyi.

Penelitian ini dirancang secara kuantitatif dan kualitatif dengan melibatkan 100 responden dari pemustaka di perpustakaan lingkungan ISI Surakarta yang meliputi perpustakaan Jurusan Karawitan, Jurusan Pedalangan, Jurusan Tari, dan Perpustakaan Pusat ISI Surakarta. Setelah dilakukan distribusi kuesioner dan dianalisis

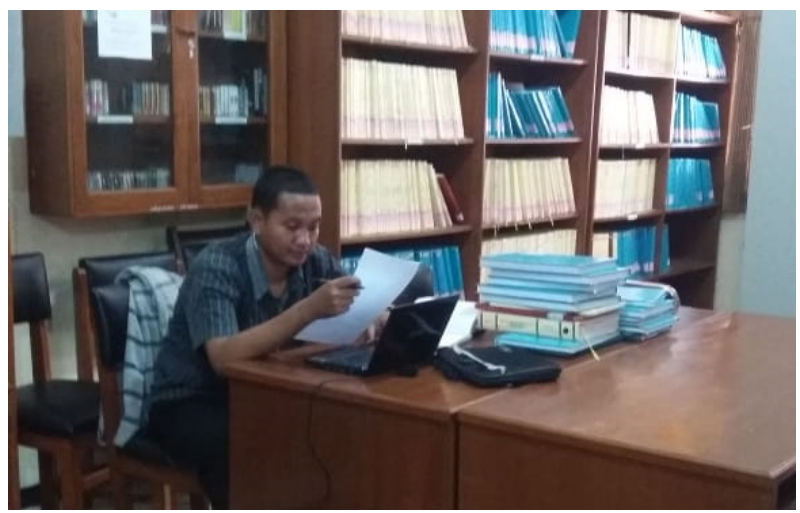

Gambar 3: Potret suasana dan pemustaka di Perpustakaan Jurusan Seni Tari ISI Surakarta. (Foto: Sartini, 2019) 
hasilnya ditemukan bahwa, $70 \%$ responden menyatakan tidak terganggu, dengan berbagai alasan yang mendasarinya. Kebanyakan responden memiliki anggapan bahwa suara gamelan yang terdengar hingga perpustakaan tidak mengganggu. Karena para pemustaka menganggap, suara gamelan sudah menjadi fenomena bunyi yang terdengar setiap hari. Oleh sebab itu alam bawah sadar mereka menganggap suara gamelan bukan gangguan, tetapi pemandangan auditif yang lazim. Anggapan penting dari beberapa responden adalah bahwa suara gamelan sudah kasarira atau embodied cognition di alam bawah sadar mereka (Simatupang, 2013: 75). Oleh sebab itu tidak mengganggu dalam aktivitas kenyamanan dalam berliterasi di UPT Perpustakaan ISI Surakarta.

Ada $15 \%$ responden menyatakan suara gamelan dianggap sebagai polusi, dan mengganggu aktivitas literasi di lingkungan ISI Surakarta. Anggapan itu lantaran suara gamelan dianggap sebagai kebisingan publik. Para pemustaka butuh kenyamanan dan terhindar dari segala polusi auditif apapun, termasuk suara gamelan dan yang lainnya. Sisanya 15\% menganggap biasa saja, karena konsepsi kenyamanan mereka tidak ditentukan oleh gangguan auditif. Kendati mayoritas pemustaka tidak terganggu atas suara gamelan tetapi yang menjadi hal penting adalah alasan mereka atau argument pemustaka mengapa tidak terganggu oleh suara gamelan.

Untuk memahami persepsi para pemustaka di lingkungan ISI Surakarta tidak hanya dilakukan dengan kuesioner, akan tetapi dengan wawancara juga dilakukan untuk memperdalam dan mengetahui seperti apa persepsi pemustaka atas suara gamelan di lingkungan perpustakaan. Beberapa narasumber menyatakan bahwa suara gamelan sudah menjadi hal yang normal baik itu di perpustakaan maupun di tempat lain, namanya kampus seni, gamelan menjadi pemandangan yang wajar. Menurut Wahyu Widhayana, salah satu

Tabel 1: Presentase indikator persepsi.

\begin{tabular}{cc}
\hline Presentase & Indikator Persepsi \\
\hline $70 \%$ & Tidak mengganggu \\
$15 \%$ & Menganggu \\
$15 \%$ & Biasa saja \\
\hline
\end{tabular}

pemustaka menyatakan bahwa suara gamelan kadang menjadi hiburan.

"Suara gamelan juga menjadi hiburan di saat membaca dan berfikir. Karena musik gamelan membuat nyaman dan tenang saat berada di perpustakaan. Jadi menurut saya biasa saja tidak mengganggu ... semua tergantung bagaimana masing-masing pribadi memaknai gamelan sebagai apa dan seperti apa ..." (Wawancara Widhayana, 10 Agustus 2019).

Paparan di atas menandai preferensi seseorang tentang kenyamanan, berbanding lurus dengan apa yang keseharian mereka dengarkan. Psikologi manusia dapat beradaptasi dan berimajinasi sesuai dengan apa yang ada di lingkungan mereka. Selama kenyamanan itu tidak berdampak langsung kepada fisik, manusia memiliki ukuran sendiri-sendiri sesuai pengalaman ketubuhan yang dialaminya. Dalam posisi ini pengalaman manusia berada pada posisi sentral, oleh sebab itu mengkaji persoalan yang berkaitan dengan pengalaman, seperti melihat persepsi pemustaka terhadap suara gamelan, sebagai kajian tentang pengalaman, disebut dengan istilah the scientific study of experience (Jackson, 1993: 2).

Narasumber dari pemustaka yaitu Jaka Tri Hutama juga menyatakan hal yang hampir sama dengan hal di atas. Menurutnya aktivitas literasi di UPT Perpustakaan ISI Surakarta memiliki kekhasan tersendiri. Mendengarkan gamelan menjadi hal yang menyenangkan seperti merasa diberikan ilustrasi ketika membaca atau mengerjakan tugas di ruang perpustakaan.

"Saya seorang dalang, bunyi gamelan, seolah menjadi pemandangan audio seharihari bagi saya. Suara gamelan membuat saya nyaman dan membuat saya senang. Hubungan emosional saya dengan gamelan seolah tidak hanya berada di panggung, tetapi juga terjadi di luar pementasan...jadi selama suara gamelan tersebut masih dalam tatanan wajar, tidak berlebihan secara volume, bagi saya tidak mengganggu aktivitas saya di perpustakaan”. (Wawancara Hutama, 11 Agustus 2019).

Hal menarik lainnya dinyatakan oleh Viona Prayuswesti, menurutnya sejak kecil dia melatih 
konsentrasi belajar dengan mendengarkan musik. Semenjak kuliah di ISI Surakarta Jurusan Karawitan, dia mengaku menjadi pengalaman baru karena yang ia dengar adalah musik gamelan. Ia merasa sangat nyaman ketika sayup-sayup suara gamelan melintas sebagai pemandangan auditif.

\section{Implikasi terhadap Kenyamanan Pemustaka}

Pengertian kenyamanan menurut Kolcaba (2003) adalah kondisi dimana manusia telah memenuhi kebutuhan dasarnya yang bersifat individual dan holistik, sehingga tercipta perasaan sejahtera pada diri individu tersebut. Karena berlatar belakang sebagai seorang perawat maka pengelompokan terhadap kenyamanan juga sedikit berbeda, dimana unsur interaksi manusia lebih menjadi faktor penting.

Aspek kenyamanan terbagi menjadi sebagai berikut: (a) Kenyamanan fisik, merupakan jenis kenyamanan yang dapat dirasakan langsung oleh sensasi tubuh setiap orang; (b) Kenyamanan psikospiritual, merupakan jenis kenyamanan yang berkenaan dengan kesadaran internal diri, yang meliputi konsep diri, harga diri, makna kehidupan, seksualitas hingga hubungan yang sangat dekat dan lebih tinggi; (c) Kenyamanan lingkungan berkenaan dengan lingkungan, kondisi dan pengaruh dari luar kepada manusia seperti temperatur, warna, suhu, pencahayaan, suara, dll; (d) Kenyamanan sosial kultural berkenaan dengan hubungan interpersonal, keluarga, dan sosial atau masyarakat.

Dalam konteks ini, kenyamanan dalam berliterasi termasuk ke dalam kenyamanan lingkungan. Kenyamanan lingkungan dalam perspektif tulisan ini mengacu kepada kenyamanan ruang perpustakaan yang secara langsung terpapar suara gamelan dari aktivitas perkuliahan. Secara garis besar, hasil dari analisis responden melalui kuesioner dan wawancara dapat ditarik

Tabel 2: Presentase indikator kenyamanan.

\begin{tabular}{cc}
\hline Presentase & Indikator Kenyamanan \\
\hline $60 \%$ & Nyaman \\
$20 \%$ & Tidak Nyaman \\
$20 \%$ & Biasa saja \\
\hline
\end{tabular}

pemahaman bahwa kenyamanan atau ukuran kenyamanan itu dipengaruhi oleh preferensi tentang pengalaman hidup manusia. Jika kajian penelitian ini menempatkan gamelan suara sebagai objek untuk mengetahui sejauhmana pengaruhnya terhadap kenyamanan lingkungan yang dalam hal ini perpustakaan maka sudah barang tentu pengalaman menjadi indikator penting. Oleh sebab itu, informasi yang dihimpun dari para responden selalu ditekankan kepada hubungan emosionalnya dengan gamelan. Jadi secara tidak langsung maka orang-orang tertentu yang secara emosional belum memiliki pengalaman yang mendalam dengan gamelan yang dalam kontek penelitian ini menyatakan kurang nyaman meskipun berskala kecil.

Dari 100 responden terdapat $60 \%$ menyatakan nyaman, dan $20 \%$ biasa saja, sementara $20 \%$ sisanya menyatakan tidak nyaman. Kenyamanan tersebut diukur melalui instrumen pertanyaan yang mengaitkan dengan paparan suara gamelan. Jawaban responden ada $60 \%$ yang menyatakan nyaman secara auditif. Indikator tersebut tidak mempertimbangkan kondisi ruang dan fasilitas perpustakaan tetapi dilihat dari gangguan auditif yang berpengaruh terhadap psikologi para pembaca. Responden yang menjawab biasa saja ada $20 \%$, karena menganggap bukan hal yang perlu dipertimbangkan untuk menjadi hal penting. Bagi mereka kebutuhan dasar literasi adalah kelengkapan koleksi.

Dari Tabel 2 tersebut menunjukan kriteria kenyamanan dapat dikonstruksi dengan mengambil bagian dari psikologi manusia. Secara alamiah maka paparan musik tertentu dapat mempengaruhi psikologi manusia dalam konteks apapun. Menurut Djohan (2003) dalam kehidupan sehari-hari, emosi ditimbulkan oleh kondisi lingkungan yang nyata yang secara realistis sulit terkontrol, misalnya kecelakaan lalulintas. Walaupun musik juga dapat menakutkan dan mengancam tetapi selalu ada rasa kontrol misalnya dengan mematikan musik tersebut atau dengan tidak mendengarkannya sama sekali. Di sini penggunaan kata 'emosi' sulit diartikan dalam konteks musik. Dalam penelitian tentang emosi sebagai respon terhadap musik biasanya hanya ditujukan pada karakter khusus emosi 
yang sifatnya menggetarkan. Menurut Sloboda dalam Djohan (2003: 41) dijelaskan bahwa musik dapat meningkatkan intensitas emosi dan lebih akurat bila 'emosi musik' itu dijelaskan sebagai suasana hati (mood), pengalaman, dan perasaan yang ditimbulkan karena proses mendengarkan musik. Di sini musik juga memiliki fungsi sebagai katalisator atau stimulus bagi timbulnya pengalaman emosi. Menurut Merriam (1964: 163) menjelaskan bahwa musik dapat mempengaruhi organisme dengan cara-cara lain, musik dapat meningkatkan produksi maupun kepuasaan di saat bekerja.

Melihat penjelasan teori-teori psikologi di atas maka akan membawa kajian ini ke arah yang lebih abstrak karena menyangkut emosi manusia. Tetapi hal itu secara kongkret terjadi sebagai bahan pertimbangan penilaian pustakawan terhadap pemustaka yaitu untuk menggali sejauhmana suara gamelan juga mempengaruhi psikologi mereka untuk tetap nyaman atau sebaliknya di dalam ruang perpustakaan.

Dari data tabel-tabel tersebut maka jawaban dari responden berdasarkan hasil kuesioner dan wawancara secara mendalam diperoleh jawaban yang memiliki sifat persepsi yang secara langsung mengarah kepada aspek psikologi. Mengapa demikian karena kenyamanan merupakan hal abstrak yang dialami oleh manusia terkait dengan mental imajinasi yang menimbulkan rasa atau perasaan. Dua hal itulah yang secara disiplin ilmu masuk ke arah psikologi.

\section{Kesimpulan dan Saran}

Dari penjelasan dan pembahasan berdasarkan data yang diperoleh maka ada beberapa kesimpulan yang dapat diambil yaitu:

1. Suara gamelan dianggap lazim oleh pemustaka yang berada di dalam kampus seni dan dirasa bukan menjadi hal yang menggangu dalam aktivitas berliterasi.

2. Suara gamelan dianggap sebagian pemustaka sebagai hal yang memberikan pengaruh baik terhadap kenyamanan mereka, artinya secara psikologi memberikan dampak baik dan tentu membuat nyaman di dalam ruangan.
3. Kenyamanan selalu berbanding lurus dengan pengalaman ketubuhan manusia, suara gamelan merupakan entitas yang menjadi pengalaman mayoritas mahasiswa ISI Surakarta, sehingga di dalam aktivitas literasi tidak menjadikan gangguan secara umum.

\section{Kepustakaan}

Bandono, Susilowati. Pengaruh Pelayanan Perpustakaan Terhadap Prestasi Akademik Mahasiswa Fakultas Seni Rupa ISI Yogyakarta. Abdi Pustaka, Jurnal Perpustakaan dan Kearsipan. Vol.1 No.1 - Juni 2021: 15 - 24. https://doi.org/10.24821/jap.v1i1.5916

Diny Ruti Elvandari, M Hermintoyo. 2014. "Pengaruh Musik Klasik Terhadap Kenyamanan Pemustaka di UPT Perpustakaan Universitas Pancasakti Kota Tegal Jawa Tengah”. Jurnal Ilmu Perpustakaan, Volume 3, No. 1.

Djohan Salim. Psikologi musik. Yogyakarta: Best Publiser, 2009.

Jackson, Michael. 1996. "Introduction: Phenomenology, Radical Empiricism, and Anthropological Critique" dalam Things A They Are, New Direction in Phenomenological Anthropology. Michael Jackson (Ed.), Bloomington and Indianapolis: Indiana University Press.

Kolcaba, K.Y. 1994. "A Theory of Holistic Comfort for Nursing". Journal of Advance Nursing", No. 19, 1178-1184

Kolcaba, K.Y., \& Fisher, E.M. 1996. "A Holistic Perspective on Comfort Care as an Advance Directive". Critical Care Nursing, No. 18, hlm 66-76.

Kolcaba, K.Y., \& Wilson, L. 2004. "Practical Application of Comfort Theory in the Perianesthesia Setting”. Journal of PeriAnasthesia Nursing, Vol. 19 No. 3, hlm 164-173.

Kolcaba, K.Y., Tilton, C., \& Drouin, C. 2006. "Comfort Theory a Unifying Framework to Enhance the Practice Environment". The Journal of Nursing Administration, Vol. 36, No. 11, hlm 538-544. 
Merriam, Alan P. Antropologi Musik. Terj. Triyono Bramantyo. Yogyakarta: Perpustakaan ISI Yogyakarta, 2001.

Penny Ismiati Iskak dan Juznia Andriani. 2014 "Persepsi Pemustaka Terhadap Kenyamanan Ruangan Perpustakaan di Pusat Perpustakaan dan Penyebaran Teknologi Pertanian”. Jurnal Perpustakan Pertanian Kementrian Pertanian Republik Indonesia. Volume 23, No. 1, hlm 32-38.

Rudi Sumadi. 2016. "Peranan Desain Interior Perpustakaan Bagi Pemustaka di Perpustakaan P3DSPBKP”. Jurnal Pari. Volume 2, No. 1. hlm 25-30.

Rita Yulianti. 2013. "Perbaikan Ergonomi Lingkungan Internal Perpustakaan untuk Peningkatan Kenyamanan dan Performansi Kerja Pemustaka: Studi Kasus Perpustakaan Jurusan Teknik Mesin dan Industri Fakultas Teknik UGM". Jurnal Berkala Ilmu Perpustakaan dan Informasi. Volume IX, No. 1, hlm 14-19.

Sugeng Wahyuntini, Sri Endarti. Tantangan Digital dan Dinamisasi Koleksi dalam Pemanfaatan Koleksi Perpustakaan bagi Prestasi Belajar Mahasiswa. Abdi Pustaka, Jurnal Perpustakaan dan Kearsipan. Vol.1 No.1 - Juni 2021: 1-6. https://doi.org/10.24821/jap.v1i1.5909

Sugiyono. 2013. Metode Penelitian Manajemen.
Bandung: Alfabeta.

Tim Penyusun. 2019. "Panduan Pelaksanaan Penelitian dan Pengabdian Masyarakat” ISI Surakarta.

\section{Webtografi}

Elza Astari Retaduari. “Tumbuhkan Minat Baca Masyarakat, Perpustakaan Cikini Siapkan Ruang Musik”. Dilansir oleh Detiknews pada Jumat 29 Mei 2015 pukul 08:00. Diakses pada Kamis 04 April 2019 pukul 16:01 WIB. Alamat web: https://news.detik.com/ berita/d-292823`3/tumbuhkan-minat-bacamasyarakat-perpustakaan-cikini-siapkanruang-musik.

Public Library Amsterdam diposting 14 Mei 2014 pukul 01:00 waktu setempat, diakses 05 April 2019, pukul 10:45 WIB. Alamat web: https:// www.archdaily.com/505344/public-libraryamsterdam-jo-coenen-and-co-architekten.

http://thecomfortline.com

\section{Narasumber}

Hutama, Mahasiswa Jurusan Pedalangan ISI Surakarta.

Widhayana, Mahasiswa Jurusan Karawitan ISI Surakarta. 